\title{
Nature-Based Solutions and Real-Time Control: Challenges and Opportunities
}

\author{
José Artur T. Brasil 1,*, Marina B. de Macedo ${ }^{1}$, Thalita R. P. de Oliveira ${ }^{1}$, Tassiana H. Oliveira ${ }^{1}$, \\ Marcus N. Gomes Júnior ${ }^{3}$, Cesar A. F. do Lago ${ }^{1}$, Eduardo M. Mendiondo ${ }^{2}$ \\ 1 Researcher, Hydraulic Engineering and Sanitation, University of Sao Paulo, Av. Trabalhador \\ Sãocarlense,400 CP 359 São Carlos, SP CEP, 13566-590, Brazil; arturtbr@usp.com \\ 2 Assistant Professor, Hydraulic Engineering and Sanitation, University of Sao Paulo, Av. Trabalhador \\ Sãocarlense, 400 CP 359 São Carlos, SP CEP, 3566-590, Brazil; emm@sc.usp.br \\ 3 Graduate Research Assistant, Department of Civil and Environmental Engineering, University of Texas at \\ San Antonio, One UTSA Circle, San Antonio, TX, 78249, USA ; marcus.gomesjunior@utsa.edu \\ * Correspondence: arturtbr@usp.br
}

\begin{abstract}
Nature-based Solutions (NBS) as green infrastructures to urban drainage, has proven to be an effective mitigation strategy both in terms of quantity and quality of runoff. The Real-time Control (RTC) can complement to both flood mitigation and improvement of water quality through the control of the elements of the drainage and sewage system. This study assessed the improvement opportunities of three NBS related techniques commonly applied in urban drainage with different spatial scales were selected: green roof, bioretention and detention basin when applied with RTC and the remaining challenges to integrating both methods. Additionally, our investigations showed that the main difficulties reported involve the planning stage of the RTC system. All of the studied devices can benefit from RTC. It is possible to observe that despite the good results reported in the literature, the application of RTC at the NBS studies on urban drainage are very recent. There are several opportunities that can be explored to optimize the performance.
\end{abstract}

Keywords: nature-based solution; real-time control; urban resilience; water quality improvement

\section{Introduction}

Urban development and the impervious surfaces growth increase the volume of stormwater runoff, the associated peak flow, pollutant loads and concentrations, in addition to reduce the runoff concentration time [1]. Besides, the climate changes tends to aggravate the impact on urban drainage systems due to the increase in the occurrence of extreme events [2]. The traditional solutions to flood control is to enlarge the drainage system infrastructure or expand the capacity of existing structures in order to rapidly transport water to downstream [3,4]. However, in addition to not solving the flood problem, the costs associated to these solutions are high and, as urbanization advances, new expansions are needed at the systems.

In this way, the stormwater source control approaches gain prominence as viable solutions for improving urban resilience that, in a decentralized manner, allows a reduction in the impact of natural disasters and impacts caused by environmental changes both quantitatively and qualitatively [5-7]. The Nature-based Solutions (NBS) are solutions inspired, which use and/or are supported by nature and are defined as living solutions in which processes and structures are designed to meet different environmental challenges, while simultaneously providing several economic, social and ecological benefits $[8,9]$.

Regarding to urban drainage, NBS are associated with the concept of Low Impact Development (LID). By analyzing a historical context, the LIDs initially aimed to reintegrate the excess runoff into the hydrological cycle [10]. With the advances of techniques, the LID incorporated objectives to mitigate the impacts caused by climate change, in addition to proposing to reintegrate the volume of water drained into the basin through local reuse [11, 12]. Therefore, incorporating future medium 
and long term time scales, considering the increased occurrence of extreme flood and drought events, and aiming at recycling and comanagement of resources, LIDs can contribute to different United Nations Sustainable Development Goals (UN SDG).

LIDs stand out for providing reduction of peak flow and diffuse pollution through related physical-chemical process such as filtration and drainage layers at the systems [10]. However, dispite the most varied designs, these systems are projected to function passively, i.e they are not adapted for internal storage (formation of a saturated layer) or free drainage to optimize aerobic, anaerobic and/or hydraulic process at the layers [13].

In this way, the application of techniques such as Real-time Control (RTC) can assist in the system operation and optimization. The RTC allows to modify the state of one or more elements in which it adjust the system configuration based on continuous monitoring and/or forecast [14]. The first RTC application in urban drainage was implemented in Minneapolis (USA) in the late 1960s [15]. Since then, RTC strategies have been developed and applied in several urban drainage systems around the world, especially in Europe and North America, generally with the objectives of reducing storage tanks volume in Combined Sewage Overflow (CSO) systems, to prevent urban flooding or minimizing operacional costs $[15,16]$.

However, applying RTC to urban drainage has several operational challenges. [17] indicates that, although a large part of the monitoring, data transmission and even control elements necessary for the operation of the RTC are already available in the urban drainage system, the type and scope of the elements necessary for the application of the RTC occurs in function of the complexity of the system. Another determining factor for the use of RTC is the control strategy, since it can be decentralized or centralized, and, when opting for more sophisticated systems that rely on automatic sensors, acquisition, data processing and control of the actuators, the practical implementation can be expensive [18].

Despite the reported benefits of the NBS and RTC application in the urban drainage systems, there is only few literature on the application of the two techniques together. Therefore, this paper aims to qualitatively explore the opportunities for joint application of both techniques (NBS + RTC), report the main challenges found in the literature regarding the integration of RTC and perform a comparative analysis of NBS techniques and their potential benefits associated with application of RTC. The RTC identification of how RTC can contribute to different techniques, accentuate the potential benefit and identify the application challenges aims contribute to the $16^{\text {th }}$ unsolved problem in hydrology: "How can we use innovative technologies to measure surface and subsurface properties, states and fluxes at a range of spatial and temporal scales?"[19].

\section{Predominant NBS, RTC history and opportunities}

Among the NBS applied to the urban drainage system, we selected different techniques in order to analyze different application scales. To property scale, green roofs were selected. At street scale drainage system, bioretention were selected. And to neighborhood to watershed scale, detention basins were investigated. For this study, a brief literature review on the operation, design and experimental results of these techniques was carried out, as well as, when applicable, the history of RTC application. In each technique, it was also indicated where the RTC can act to enhance the existing benefits or even bring new uses to the device.

\subsection{Green roof}

In developed cities, roof areas account for about $40-50 \%$ of total impermeable surfaces urban areas [20]. Therefore, in urban areas, the application of green roofs has growing attention due to environmental benefits and energy efficience. A green roof is a layered system containing a waterproofing membrane, growing media (usually a soil mix) and the vegetation layer itself. Green roofs often also include a root barrier layer, drainage layer and, where the climate necessitates, an irrigation system [20].

The most vital and interesting part of the development of green roof is the selection of vegetation layer, which maximize the green roof life. The success of green roofs depends on plant's health [21]. 
Vegetation/Plants of green roofs improve the runoff water quality [22,23], air quality [24] and reduce the heat waves at the roof surface [25]. Therefore, the optimum selection of this growing media must be necessary for the success of a green roof [21]. The choice of the substract should be based in several characteristics as weight of the substract, hydraulic conductivity, moist weight, longevity and plant support and by the given sorption capacity of the substract [22,26]. Most of the green roof benefits are directly correlated with the substrate of green roofs such as water quality enhancement, runoff reduction, peak flow reduction and thermal benefits [27-29]. To separate the growing media from the drainage layer, a filter layer of green roofs is used to prevent smaller particles such as soil fines and plant debris from entering and clogging the drainage layer [21].

Several studies shows that green roofs can reduce the surrounding air temperature [20], Stormwater retention to reduce peak flow and runoff [26,30,31], water quality enhancement for water utilization [21,22], Air cleaning for easy comfort into urban areas [31], noise reduction [32], ecological benefits [21,23,25], social and economic benefits [33].

Green roofs also can also storage water to re-use purpose witch offers a sustainable and aestethical treatment solution to irrigate the green roof at dry periods or as a supplemental water to non potable use [34]. The green blue roof is a modified green roof with an additional storage layer to achieve both reduction of peak flow, water reuse and to reduce heat waves at the roof surface [35].

No specific literature was found on RTC over green roofs, but as the technique allows to storage water, the RTC can improve some of the objectives at green roofs. The green roofs can function as water storage tanks which are applied in several cases with RTC at urban drainage [15,36], with the pre-treatment benefits of green roof media and vegetation. Even descentralized RTC can improve the water quality at the reservoir bypassing the first flush of stormwaters, control the water level at the reservoir and avail the water to maintain the vegetated layer. At an urban watershed, centralized RTC applied at green roofs can delay the peak runoff and improve the water quality simultaneously as the individual reservoirs are controlled to optimize the objective.

\subsection{Bioretention}

The bioretention systems, are techniques that uses soil compositions and vegetations to promote stormwater runoff infiltration, evapotranspiration, pollutant removal and uptake by plants, in addition to provide aesthetic and social benefits [1,37]. Generally, the bioretention systems are composed from top to bottom of vegetaded layer, a soil mix media layer also called filter media, and a drainage layer typically composed by coarse aggregate.

The vegetation is an important element of bioretention systems and contributes to the hydrologic function above, at, and below the filter media surface, through plant interception of rainwater, surface flow regulation, water infiltration modification, and plant transpiration [38]. The selection of the vegetation is decisive to the required design treatment, as the vegetation have an important role in pollutant removal and plant uptake. The vegetation is also responsible for media stabilization and to minimize the media movement in the bioretention cell, improving the long term TSS removal [39]. The vegetation also assist the nitrogen removal through biological, hidrological and plant uptake mechanisms, phosphorus removal by plant uptake, plant alteration of the media and the reintroduction of phosporus bye the senesced biomass, can facilitate metal removal through direct plant uptake including hyperaccumulation [39-42].

Related to the drainage layer design, the bioretention cells are divided in free draining and with internal water storage. Free draining have shown good results at literature, but are domintated by aerobic conditions and lack to perform both nitrification and denitrification [42-44]. Therefore, bioretention cells with interal water storage promote aerobic and anaerobic conditions favoring both nitrification and denitrification $[13,45]$.

The literature shows both quantitative and qualitative favorable results. Numerous studies have indicated that bioretention systems are very useful to control runoff in urban areas, with runoff reduction of $36-96 \%$ depending on the rainfall intensity [1,46,47]. A bioretention system can also increases the time of concentration $[1,48]$. 
Although, some concern has been raised that bioretention performance is affected by clogging, caused due to the presence of small-sized silt and fine particles in the run-off [47,49]. Bioretention facilities are effective to improve the water quality in urban areas. Different field studies have shown that bioretention cells can remove the metals commonly found in urban drainage such as $\mathrm{Zn}, \mathrm{Cu}, \mathrm{Fe}$, $\mathrm{Cd}, \mathrm{Mn}$ and $\mathrm{Pb}[41,43,50,51]$. Nutrients removal depends on media type, drainage configurations and the vegetation, although several studies show a removal efficiency of 32-97\% for total nitrogen and $29-85 \%$ for total phosphourous [46]. Bioretention cells also presents a high TSS removal from the drainage system, reaching over $99 \%$ of removal rate [46].

Specific studies of a descentralized RTC at bioretentions cells are recent. [52] studied treatment of stormwater to harvesting and reuse. The author used two low-cost implementation strategies for both new cells and for cells already built and found that bioretention with RTC can mitigate the negative effects of short and long dry periods and mitigate the influence that large inflow volumes have on the treatment of faecal microbes. [13] analyzed several RTC schemes in bioretention columns to improve water quality. The most notable water quality improvement was related to nutrients, while the static system performed best to ammonium by more than $40 \%$ and columns with internal water storage removed more nitrate by more than $73 \%$. They also suggest that active control and RTC may strike a balance between traditional free drainage and internal water storage systems. However, scientific gaps stills exists on RTC on bioretentions systems, such as lacks in questions about centralized analysys over several bioretention cells, quantitative aspects of runoff and peak flow reduction and multiple objectives RTC.

\subsection{Detention basin}

A detention basin is a structural measure to manage floods by temporarily storing a portion of the incoming water volume in selected areas [53]. The outflow from the detention basin depends on the type and size of the outlet structure. A detention basin has at least one primary outlet, such as an orifice, weir, or riser type outlet, to pass the regulated flow from the basin and one secondary outlet (emergency spillway) to pass the overflow above the basin storage during rainy seasons [54]. Conventional detention basins are designed for flooding protection purpose, the measure have little water quality benefits, although some design strategies can improve the pollutant removal. [55] develop a two stages detention basin. The bottom stage has a small outlet to promote settling of pollutants, while the top stage remains dry except during large storms.

Detention basins can also be classified as inline or offline. While inline basins may cause water to build up and flood land upstream, offline basins do not create any barriers to sediment transport and fish migration [53]. Also, properly designed offline basins are often turned into wetlands, enhancing ecological diversity, or recreational areas [56].

Detention basins are large-scale devices and are directly connected to urban drainage system. Several results shows that detention basins have good performance avoiding flood downstream, however water quality can be an issue [57]. The detention basin cycle over rainy and dry seasons can accumulate sediments. [58] characterized the sediments in a 32,000 $\mathrm{m}^{3}$ detention basin in order to infer their contamination and health hazards. The detention basin was found to have high metal concentrations and polluted by faecal bacterias.

In order to improve quality performance at detention basins, [57] used RTC algorithms to control a simulated detetion basin. While passive device have shown $64 \%$ of TSS removal efficiency, the performance of detention basin with RTC were 95\%. [59] studied the aplication of RTC in detention basins as adaptation in mid-size cities. The author concludes that when applied locally, RTC makes it possible to qualitatively and quantitatively manage the whole range of rainfall events in a given year and to better face any possible changes in future precipitations. In the case of smaller events, closing the control gate helped increase detention time and, therefore, has the potential for improved water quality before this water is discharged into the receiving water body.

Despite the incipient applications of RTC in detention basins, there are several application opportunities. [56] analyzed an offline detention basin with passive and active controls, although RTC algorithms could be applied to this scenario to evaluate both quantitative and qualitative 
performance at an ecobased design. Multiobjective RTC also could be applied to reduce TSS and therefore the contaminants. RTC also can be applied in an integrated manner with urban drainage.

\section{Challenges to apply RTC at NBS}

Planning a RTC system is a complex process [16]. As it is a system that has a high implementation cost, some decisions must be made in the planning stage [17]. An important decision at this stage is to define whether the system will be centralized or decentralized. Centralized systems tend to perform better, since the management is performed in an integrated way, however they are more complex, expensive and need central control [17]. Alternatives aiming at spatially distribution, such as green roofs, include even greater complexity compared to centralized systems, since they would require a large amount of equipment for monitoring and control, being more feasible in these cases to use a more decentralized approach. Regarding bioretention cells, the scale of application can influence the decision on the type of control, while for detetion basins, since it is a device usually located in low points of the basin, the centralized approach is more interesting, as it can adapt its operation depending on the state of the drainage system.

Another important factor in the implementation of RTC systems is the monitoring and control equipment. However, when it comes to NBS, there is an extensive literature on sensors of the most varied types and functions, since the measuring techniques for the different variables and parameters for each technique evolved in parallel with the experimental studies. Therefore, a large part of the cost necessary for the implementation of monitoring equipment has already been applied to NBS techniques. The large part of the cost needed in this step would be to transmit the data in real time, as well as with the control devices. [59] reviewed the main technical requirements of sensors for installing a system with RTC.

The RTC often requires a mathematical modeling of the system and short term forecast, therefore the implementation of these aspects may be time and cost expensive and can increase the uncertainty depending the nature of the system [16]. The reliability of the system have to be discussed as a failure could impact both the runoff and water quality causing flood events and decreasing water quality. Consequently, the maintance of the system cannot be neglected due to the negative effects that can be caused by the failure of the system $[17,60]$. Although little mentioned in the literature on RTC in urban drainage systems, it is also important to account with the cyber-security. Since RTC systems rely on online connections to receive data and send controls, hacker attacks can impair the functioning of the devices.

\section{Comparative analysis and Discussion}

Despite the differences in the analyzed techniques scale, it is possible to make a comparison between the different NBS in order to summarize what was discussed about the opportunities and challenges of RTC implementation. The Table 1 summarize the comparative analysis:

Table 1. Comparative analysis on discussed NBS to RTC implementation

\begin{tabular}{ccccc}
\hline & $\begin{array}{c}\text { Literature on } \\
\text { RTC }\end{array}$ & $\begin{array}{c}\text { Descentralized } \\
\text { RTC } \\
\text { possibilities }\end{array}$ & $\begin{array}{c}\text { Centralized } \\
\text { RTC } \\
\text { possibilities }\end{array}$ & $\begin{array}{c}\text { Implementation } \\
\text { costs }^{1}\end{array}$ \\
\hline Green roof & - & + & -+ & ++ \\
Bioretention & + & ++ & + & -+ \\
Detention basin & + & + & ++ & - \\
\hline
\end{tabular}

${ }^{1}$ The implementation costs depend on the sensors and equipment that are usually found in the respective literature of each technique.

From the studies on the application of RTC in NBS, it is possible to observe that few papers have been published on the topic. Since no specific studies for RTC were found on green roofs, this technique was evaluated as having the lowest performance in this regard. 
For decentralized real-time control applications, bioretention presented a greater potential than other techniques, since bioretention cells allow good results, both in terms of runoff quantity control and water quality improvement, although there is also a potential for improvement for other techniques in a decentralized application form. Here, we emphasis on green roofs, as they are techniques applied on a smaller scale and require a reservoir structure that is not always present in the its design.

For centralized applications, detention basins are more recommended, as they work on a larger scale and can be integrated with the drainage system. Green roofs can also benefit from centralized controls, however the complexity is relatively high, since for a watershed drainage scale it would be necessary to apply a large amount of green roofs for the effect to be positive. As the literature on bioretentions shows applications with different scales, the device can benefit from centralized controls for specific cases of application in watershed scales.

The scale of the green roofs also help in this cost increase, since each green roof must have its own monitoring structure, leading to a higher number of sensors employed and a sending and receiving data structure more expensive than for the other techniques. For bioretention techniques, the cost of implementation depends strongly on the device design. If the device already has a structure for storage and/or underdrain, the cost is reduced. For detention basins, most devices are already in installed or in operation, making real-time control cheaper than when compered to other techniques.

\section{Conclusions}

In this paper, the challenges and opportunities of applying RTC in NBS were evaluated. Three techniques commonly applied in urban drainage with different spatial scales were selected: green roof, bioretention and detention basin. A brief review of the design of the techniques and the results was carried out, both for runoff quantity and water quality. The existing literature on the application of RTC in these techniques was also evaluated. From these observations, several opportunities for application of RTC have been reported.

For green roofs, no specific literature has been found on RTC. However, as the technique has the possibility of storing water, the RTC can be employed to work similarly with water storage tanks, since the last one has already RTC applications in urban drainage. Additionally, green roofs have the advantage of a pretreatment due to the soil and plants, when compared to water storage tanks.

Bioretention studies have already been carried out with RTC application and the results were positive, both adding versatility to the device, allowing to treat ammonium and nitrate through the variation of aerobic and anaerobic zones, and improving the water quality in general for different reuses, such as in households or agricultural. However, there are still scientific gaps for the RTC implementation on bioretention, such as multi-objective analyzes, centralized controls with the drainage system, in addition to a quantitative analysis of the effects of RTC on the bioretention cells.

Studies have also assessed RTC in detention basins. It was possible to notice that RTC improved the detention basins performance both for water quantity and quality. In this case, the study opportunities on RTC for active control of the detention basin involve different designs, since offline detention basins have great potential for improvement with RTC, or multi-objective algorithms for a simultaneous assessment of runoff quantity and quality.

The main difficulties reported involve the planning stage of the RTC system. The decision of the system to be centralized or not, the mathematical models involved in the process, the forecasting system, as well as the costs involved in monitoring and transmitting data.

It is possible to observe that despite the good results reported in the literature, the application of RTC in NBS studies on urban drainage are very recent. There are several opportunities that can be explored to optimize the performance of devices that have already been proven their functioning, aiming to reduce the problems caused by urbanization and climate change in a sustainable manner.

Acknowledgments: This study was supported by FAPESP grant n. 2014/50848-9 INCT-II (Climate Change, Water Security), CNPq grant n. PQ 312056/2016-8 (EESC-USP/CEMADEN/MCTIC), FAPESP grant n. 
2017/15614-5 “Decentralized Urban Runoff Recycling Facility addressing the security of the Water-Energy-Food Nexus".

Author Contributions: José Artur T. Brasil idealized and wrote the paper; Marina B. de Macedo and Thalita R. P. de Oliveira conceived the structure and reviewed the paper; Tassiana H. Oliveira, Marcus N. Gomes Júnior, Cesar A. F. do Lago, Eduardo M. Mendiondo contributed with the discussion and reviewed the paper.

Conflicts of Interest: The authors declare no conflict of interest.

\section{Abbreviations}

The following abbreviations are used in this manuscript:

RTC: Real-time control

NBS: Nature-based solutions

LID: Low impact development

CSO: Combined Sewage Overflow

\section{References}

1. Davis, A.P. “Field performance of bioretention: Hydrology impacts," J. Hydrol. Eng., vol. 13, no. 2, pp. 9095, 2008, doi: 10.1061/(ASCE)1084-0699(2008)13:2(90).

2. IPCC, Climate Change 2014 Part A: Global and Sectoral Aspects. 2014.

3. Miguez, M.G.; Rezende, O.M.; Veról, A.P. “City Growth and Urban Drainage Alternatives: Sustainability Challenge," J. Urban Plan. Dev., vol. 141, no. 3, p. 04014026, 2015, doi: 10.1061/(asce)up.1943-5444.0000219.

4. Kwon, S. H.; Jung, D.; Kim J. H. “Development of a multiscenario planning approach for urban drainage systems," Appl. Sci., vol. 10, no. 5, pp. 1-16, 2020, doi: 10.3390/app10051834.

5. Zhang, S.; Li, Y.; Ma, M.; Song, T.; Song, R. "Storm water management and flood control in sponge city construction of Beijing," Water (Switzerland), vol. 10, no. 8, pp. 1-11, 2018, doi: 10.3390/w10081040.

6. Mcclymont, K. et al., "Towards urban resilience through Sustainable Drainage Systems : A multi-objective optimisation problem," J. Environ. Manage., vol. 275, no. July, 2020, doi:10.1016/j.jenvman.2020.111173.

7. Petrucci, G.; Gromaire, M.C.; Shorshani, M.F.; Chebbo, G. “Nonpoint source pollution of urban stormwater runoff: A methodology for source analysis," Environ. Sci. Pollut. Res., vol. 21, no. 17, pp. 10225-10242, 2014, doi: 10.1007/s11356-014-2845-4.

8. Frantzeskaki, N. “Seven lessons for planning nature-based solutions in cities," Environ. Sci. Policy, vol. 93, no. December 2018, pp. 101-111, 2019, doi: 10.1016/j.envsci.2018.12.033.

9. [van den Bosch, M.; Sang, O. “Urban natural environments as nature-based solutions for improved public health - A systematic review of reviews," Environ. Res., vol. 158, no. May, pp. 373-384, 2017, doi: 10.1016/j.envres.2017.05.040.

10. Fletcher, T.D. et al., "SUDS, LID, BMPs, WSUD and more - The evolution and application of terminology surrounding urban drainage," Urban Water J., vol. 12, no. 7, pp. 525-542, 2015, doi: 10.1080/1573062X.2014.916314.

11. Macedo, M.B.; Ambrogi, C.; Rosa, A.; Mendiondo, E.M. “Técnicas compensatórias de bioretenção para cidades resilientes: integração com nexus - água, energia, alimento.[Low impact Development practices of bioretention to resilient cities: integration with the water-energy-food nexus]". Proceedings of XXII Simposio Brasileiro de Recursos Hidricos. Florianópolis, Brazil. (in Portuguese).

12. Huang, C.L.; Hsu, N.S.; Liu, H.J.; Huang, Y.H. “Optimization of low impact development layout designs for megacity flood mitigation," J. Hydrol., vol. 564, no. February, pp. 542-558, 2018, doi: 10.1016/j.jhydrol.2018.07.044.

13. Persaud, P.P.; Akin, A.A.; Kerkez, B.; McCarthy, D.T.; Hathaway, J.M. "Real time control schemes for improving water quality from bioretention cells," Blue-Green Syst., vol. 1, no. 1, pp. 55-71, 2019, doi: 10.2166/bgs.2019.924.

14. Campisano, A.; Colas, H.; Schilling, W.; Vanrolleghem, P.A. "Real time control of urban wastewater systems - where do we stand today ?," vol. 299, pp. 335-348, 2004, doi: 10.1016/j.jhydrol.2004.08.010.

15. Borsányi, P.; et al., "Modelling real-time control options on virtual sewer systems," J. Environ. Eng. Sci., vol. 7, no. 4, pp. 395-410, 2008, doi: 10.1139/S08-004. 
16. García, L.; Barreiro-Gomez, J.; Escobar, E.; Téllez, D.; Quijano, N.; Ocampo-Martinez, C. “Modeling and real-time control of urban drainage systems: A review," Adv. Water Resour., vol. 85, pp. 120-132, 2015, doi: 10.1016/j.advwatres.2015.08.007.

17. Beeneken, T.; et al. "Real time control (RTC) of urban drainage systems - A discussion of the additional efforts compared to conventionally operated systems," Urban Water J., vol. 10, no. 5, pp. 293-299, 2013, doi: 10.1080/1573062X.2013.790980.

18. Gaborit, E.; Muschalla, D.; Vallet, B.; Vanrolleghem, P.A.; Anctil, F. "Improving the performance of stormwater detention basins by real-time control using rainfall forecasts," Urban Water J., vol. 10, no. 4, pp. 230-246, 2013, doi: 10.1080/1573062X.2012.726229.

19. Blöschl, G.; et al., "Twenty-three unsolved problems in hydrology (UPH)-a community perspective," Hydrol. Sci. J., vol. 64, no. 10, pp. 1141-1158, 2019, doi: 10.1080/02626667.2019.1620507.

20. Castleton, H.F.; Stovin, V.; Beck, S.B.M; Davison, J.B. “Green roofs; Building energy savings and the potential for retrofit," Energy Build., vol. 42, no. 10, pp. 1582-1591, 2010, doi: 10.1016/j.enbuild.2010.05.004.

21. Shafique, M.; Kim, R.; Rafiq M. “Green roof benefits, opportunities and challenges - A review," Renew. Sustain. Energy Rev., vol. 90, no. April 2017, pp. 757-773, 2018, doi: 10.1016/j.rser.2018.04.006.

22. Todorov, D.; Driscoll, C.T.; Todorova, S.; Montesdeoca, M. "Water quality function of an extensive vegetated roof," Sci. Total Environ., vol. 625, pp. 928-939, 2018, doi: 10.1016/j.scitotenv.2017.12.085.

23. Berardi, U.; GhaffarianHoseini, A.H.; GhaffarianHoseini, A. "State-of-the-art analysis of the environmental benefits of green roofs," Appl. Energy, vol. 115, pp. 411-428, 2014, doi: 10.1016/j.apenergy.2013.10.047.

24. Baik, J.J.; Kwak, K.H.; Park, S.B.; Ryu, Y.H.; "Effects of building roof greening on air quality in street canyons," Atmos. Environ., vol. 61, pp. 48-55, 2012, doi: 10.1016/j.atmosenv.2012.06.076.

25. Cook-Patton S.C.; Bauerle, T.L. "Potential benefits of plant diversity on vegetated roofs: A literature review," J. Environ. Manage., vol. 106, pp. 85-92, 2012, doi: 10.1016/j.jenvman.2012.04.003.

26. Vijayaraghavan, K.; Raja, F.D. “Design and development of green roof substrate toimprove runoff water quality: Plant growth experiments and adsorption," Water Res., vol. 63, pp. 94-101, 2014, doi: 10.1016/j.watres.2014.06.012.

27. Molineux, C.J.; Connop, S.P.; Gange, A.C. "Manipulating soil microbial communities in extensive green roof substrates," Sci. Total Environ., vol. 493, pp. 632-638, 2014, doi: 10.1016/j.scitotenv.2014.06.045.

28. Speak, A.F.; Rothwell, J.J.; Lindley, S.J.; Smith, C.L. "Rainwater runoff retention on an aged intensive green roof," Sci. Total Environ., vol. 461-462, pp. 28-38, 2013, doi: 10.1016/j.scitotenv.2013.04.085.

29. Berndtsson, J.C. "Green roof performance towards management of runoff water quantity and quality: A review," Ecol. Eng., vol. 36, no. 4, pp. 351-360, 2010, doi: 10.1016/j.ecoleng.2009.12.014.

30. Liu L.; Sun, L.; Niu, J.; Riley, W.J. "Modeling green roof potential to mitigate urban flooding in a Chinese City," Water (Switzerland), vol. 12, no. 8, 2020, doi: 10.3390/W12082082.

31. Xiao, M.; Lin, Y.; Han, J.; Zhang, G. "A review of green roof research and development in China," Renew. Sustain. Energy Rev., vol. 40, pp. 633-648, 2014, doi: 10.1016/j.rser.2014.07.147.

32. Schäffer, B.; Brink, M.; Schlatter, F.; Vienneau, D.; Wunderli, J.M. "Residential green is associated with reduced annoyance to road traffic and railway noise but increased annoyance to aircraft noise exposure," Environ. Int., vol. 143, no. March, p. 105885, 2020, doi: 10.1016/j.envint.2020.105885.

33. Bianchini, F.; Hewage, K. "Probabilistic social cost-benefit analysis for green roofs: A lifecycle approach," Build. Environ., vol. 58, pp. 152-162, 2012, doi: 10.1016/j.buildenv.2012.07.005.

34. Hardin, M.; Wanielista, M.; Chopra, M. “A mass balance model for designing green roof systems that: Incorporate a cistern for re-use," Water (Switzerland), vol. 4, no. 4, pp. 914-931, 2012, doi: 10.3390/w4040914.

35. Shafique, M.; Kim, R. "Application of green blue roof to mitigate heat island phenomena and resilient to climate change in urban areas: A case study from Seoul, Korea," J. Water L. Dev., vol. 33, no. 1, pp. 165-170, 2017, doi: 10.1515/jwld-2017-0032.

36. Zhang, P.; Cai, Y.; Wang, J. “A simulation-based real-time control system for reducing urban runoff pollution through a stormwater storage tank," J. Clean. Prod., vol. 183, pp. 641-652, 2018, doi: 10.1016/j.jclepro.2018.02.130.

37. Dagenais, D.; Thomas, I.; Paquette, S. "Siting green stormwater infrastructure in a neighbourhood to maximise secondary benefits: lessons learned from a pilot project," Landsc. Res., vol. 42, no. 2, pp. 195-210, 2017, doi: 10.1080/01426397.2016.1228861.

38. Muerdter, C.P.; Wong, C.K.; Lefevre, G.H. “Emerging investigator series: The role of vegetation in bioretention for stormwater treatment in the built environment: Pollutant removal, hydrologic function, 
and ancillary benefits," Environ. Sci. Water Res. Technol., vol. 4, no. 5, pp. 592-612, 2018, doi: 10.1039/c7ew00511c.

39. Alyaseri, I.; Zhou, J.; Morgan, S.M.; Bartlett, A. “Initial impacts of rain gardens' application on water quality and quantity in combined sewer: field-scale experiment," Front. Environ. Sci. Eng., vol. 11, no. 4, pp. 1-12, 2017, doi: 10.1007/s11783-017-0988-5.

40. Feng, W.; Hatt, B.E.; McCarthy, D.T.; Fletcher, T.D.; Deletic, A. "Biofilters for stormwater harvesting: Understanding the treatment performance of key metals that pose a risk for water use," Environ. Sci. Technol., vol. 46, no. 9, pp. 5100-5108, 2012, doi: 10.1021/es203396f.

41. Paus, K.H.; Morgan, J.; Gulliver, J.S.; Hozalski, R.M. “Effects of Bioretention Media Compost Volume Fraction on Toxic Metals Removal, Hydraulic Conductivity, and Phosphorous Release," J. Environ. Eng., vol. 140, no. 10, p. 04014033, 2014, doi: 10.1061/(asce)ee.1943-7870.0000846.

42. Li, L.; Davis, A.P. "Urban stormwater runoff nitrogen composition and fate in bioretention systems," Environ. Sci. Technol., vol. 48, no. 6, pp. 3403-3410, 2014, doi: 10.1021/es4055302.

43. Hunt, W.F.; Smith, J.T.; Jadlocki, S.J.; Hathaway, M.; Eubanks, P.R. "Pollutant removal and peak flow mitigation by a bioretention cell in Urban Charlotte, N.C.," J. Environ. Eng., vol. 134, no. 5, pp. 403-408, 2008, doi: 10.1061/(ASCE)0733-9372(2008)134:5(403).

44. Laurenson, G.; Laurenson, S.; Bolan, N.; Beecham, S.; Clark, I. The Role of Bioretention Systems in the Treatment of Stormwater, vol. 120. Elsevier, 2013.

45. Hunt, W.F.; Davis, A.P.; Traver, R.G. "Meeting hydrologic and water quality goals through targeted bioretention design," J. Environ. Eng. (United States), vol. 138, no. 6, pp. 698-707, 2012, doi: 10.1061/(ASCE)EE.1943-7870.0000504.

46. Davis, A.P.; Hunt, W.F.; Traver, R.G.; Clar, M. "Bioretention technology: Overview of current practice and future needs," J. Environ. Eng., vol. 135, no. 3, pp. 109-117, 2009, doi: 10.1061/(ASCE)07339372(2009)135:3(109).

47. Le Coustumer, S.; Fletcher, T.D.; Deletic, A.; Barraud, S.; Poelsma, P. “The influence of design parameters on clogging of stormwater biofilters: A large-scale column study," Water Res., vol. 46, no. 20, pp. 6743-6752, 2012, doi: 10.1016/j.watres.2012.01.026.

48. Macedo, M.B.; Lago, C.F.; Mendiondo, E.M.; Giacomoni, M.H. “Bioretention performance under different rainfall regimes in subtropical conditions: A case study in São Carlos, Brazil," J. Environ. Manage., vol. 248, no. July, p. 109266, 2019, doi: 10.1016/j.jenvman.2019.109266.

49. Lucke, T.; Nichols, P.W.B. "The pollution removal and stormwater reduction performance of street-side bioretention basins after ten years in operation," Sci. Total Environ., vol. 536, pp. 784-792, 2015, doi: 10.1016/j.scitotenv.2015.07.142.

50. Liu, Z.; Li, J.; Li, P.; Li, T.; Li, W. "Study of bioretention system on heavy-metal removal effect," Polish J. Environ. Stud., vol. 27, no. 1, pp. 163-173, 2018, doi: 10.15244/pjoes/74128.

51. Gülbaz, S.; Kazezyilmaz-Alhan, C.M.; and N. K. Copty, "Evaluation of Heavy Metal Removal Capacity of Bioretention Systems," Water. Air. Soil Pollut., vol. 226, no. 11, 2015, doi: 10.1007/s11270-015-2640-y.

52. Shen, P.; Deletic, A.; Bratieres, K.; McCarthy, D.T. "Real time control of biofilters delivers stormwater suitable for harvesting and reuse," Water Res., vol. 169, p. 115257, 2020, doi: 10.1016/j.watres.2019.115257.

53. Abawallo, S.S.; Brandimarte, L.; Maglionico, M. "Analysis of the performance response of offline detention basins to inlet structure design," Irrig. Drain., vol. 62, no. 4, pp. 449-457, 2013, doi: 10.1002/ird.1752.

54. Park, M.; Chung, G.; Yoo, C.; Kim, J.H. “Optimal design of stormwater detention basin using the genetic algorithm," KSCE J. Civ. Eng., vol. 16, no. 4, pp. 660-666, 2012, doi: 10.1007/s12205-012-0991-0.

55. Akan, A.O. “Design Aid for Water Quality Detention Basins," J. Hydrol. Eng., vol. 15, no. 1, pp. 39-48, 2010, doi: 10.1061/(asce)he.1943-5584.0000151.

56. Sanders, B.F.; Pau, J.C.; Jaffe, D.A. "Passive and active control of diversions to an off-line reservoir for flood stage reduction," Adv. Water Resour., vol. 29, no. 6, pp. 861-871, 2006, doi: 10.1016/j.advwatres.2005.07.015.

57. Sharior, S.; McDonald, W.; Parolari, A.J. "Improved reliability of stormwater detention basin performance through water quality data-informed real-time control," J. Hydrol., vol. 573, no. March, pp. 422-431, 2019, doi: 10.1016/j.jhydrol.2019.03.012.

58. Sébastian C. et al., "Accumulated sediments in a detention basin: Chemical and microbial hazard assessment linked to hydrological processes," Environ. Sci. Pollut. Res., vol. 21, no. 8, pp. 5367-5378, 2014, doi: 10.1007/s11356-013-2397-z. 
59. Bilodeau, K.; Pelletier, G.; Duchesne, S. "Real-time control of stormwater detention basins as an adaptation measure in mid-size cities," Urban Water J., vol. 15, no. 9, pp. 858-867, 2018, doi: 10.1080/1573062X.2019.1574844.

60. Ficchí, A. et al. "Optimal Operation of the Multireservoir System in the Seine River Basin Using Deterministic and Ensemble Forecasts," J. Water Resour. Plan. Manag., vol. 142, no. 1, pp. 1-12, 2016, doi: 10.1061/(ASCE)WR.1943-5452.0000571.

(C) 2020 by the authors; licensee MDPI, Basel, Switzerland. This article is an open access article distributed under the terms and conditions of the Creative Commons by Attribution (CC-BY) license (http://creativecommons.org/licenses/by/4.0/). 